Article

\title{
How Gender Conscious Pedagogy in Higher Education Can Stimulate Actions for Social Justice in Society
}

\author{
Marta Cuesta and Ann-Katrin Witt
}

Department of Health and Society, Halmstad University, Halmstad, 30118 Sweden; E-Mails: marta.cuesta@hh.se (M.C.), ann-katrin.witt@hh.se (A.-K.W.); Tel: +46-35-167-100 (A.-K.W.); Fax: +46-35-186-192 (A.-K.W.)

\section{How to Cite this Article}

Cuesta, M., \& Witt, A.-K. (2014). How Gender Conscious Pedagogy in Higher Education Can Stimulate Actions for Social Justice in Society. Social Inclusion, 2(1), 12-23.

\section{Copyrights}

(C) 2014 by the authors; licensee Cogitatio (Lisbon, Portugal). This article is licensed under a Creative Commons Attribution 4.0 International License (CC BY).

\section{Published by:}

\section{COGITATIO}

www.cogitatiopress.com

\author{
About the Journal \\ sion worldwide. \\ www.cogitatiopress.com/socialinclusion \\ Editor-in-Chief \\ Professor Ulf R. Hedetoft, Faculty of Humanities, University of Copenhagen, Denmark \\ Mr. António Vieira, Social Inclusion, Cogitatio Press, Portugal
}

Social Inclusion is a peer-reviewed open access journal which provides academics and policy-makers with a forum to discuss and promote a more socially inclusive society. The journal encourages researchers to publish their results on topics concerning social and cultural cohesiveness, marginalized social groups, social stratification, minority-majority interaction, cultural diversity, national identity, and core-periphery relations, while making significant contributions to the understanding and enhancement of social inclu- 


\title{
Article \\ How Gender Conscious Pedagogy in Higher Education Can Stimulate Actions for Social Justice in Society
}

\author{
Marta Cuesta and Ann-Katrin Witt * \\ Department of Health and Society, Halmstad University, Halmstad, 30118 Sweden; E-Mails: marta.cuesta@hh.se (M.C.), \\ ann-katrin.witt@hh.se (A.-K.W.); Tel: +46-35-167-100 (A.-K.W.); Fax: +46-35-186-192 (A.-K.W.) \\ * Corresponding author
}

Submitted: 3 December 2013 | In Revised Form: 24 March 2014 | Accepted: 12 May 2014 |

Published: 26 May 2014

\begin{abstract}
In order to reflect upon methods that can generate social justice and democratization, this article emphasises practical implementations connected to gender conscious pedagogy. Gender conscious pedagogy aims at overcoming the myth of objectivity by questioning, through teaching, what is considered as "common sense" and "normal". This endeavour entails acting and reflecting upon such breakthroughs as developing understanding of how gender codes influence everyday activities as well as working life. The starting point of the article initiates a norm-critic perspective for considering the effects of implementing a feminist perspective for teaching in both theory and practice. Our data was collected from alumni students who were asked to remember and reflect upon their gender studies classes and particularly upon the usefulness of this type of knowledge in connection with everyday and working life whether as a politician, lecturer, IT-manager, doctoral student, The study is grounded in a "critical hermeneutic" method. That is, the data is mirrored in and interpreted in light of the context in which the material was gathered. This article focuses on how teachers enable students to be gender confident and, as a consequence, to be gender actors outside the university in their working life. Some of the central questions asked in the study are: How are gender issues represented and integrated in the different areas of studies? What can teachers do in order to promote equality in the classroom? Are students given opportunities for understanding, internalizing and discussing gender issues and for describing and reflecting upon their experiences from gender studies courses?
\end{abstract}

\section{Keywords}

democracy; education; gender pedagogy; social justice; working life

\section{Issue}

This article is part of a regular issue of Social Inclusion, edited by Professor Ulf R. Hedetoft (University of Copenhagen, Denmark).

(C) 2014 by the authors; licensee Cogitatio (Lisbon, Portugal). This article is licensed under a Creative Commons Attribution 4.0 International License (CC BY).

\section{Introduction}

One of the gravest obstacles to the achievement of liberation is that oppressive reality absorbs those within it and thereby acts to submerge human beings' consciousness. Paulo Freire (1993, p. 33)

In recent years the authors of this article have become aware of many examples of how some of our former students have become gender-actors in the sense that they act confidently in their knowledge of how gender is constructed, reproduced and transformed when situations or questions of equality appear and democratic rights are on the agenda. Students have given us examples from their private lives and we have seen evidence of gender activism in their working lives. We have met our former students at conferences, read about them and seen them being interviewed in me- 
dia, read their articles and followed their blogs. Sometimes we have even met them in the street and talked about their current lives and the times when they were students in gender classes. We were positively surprised to hear that after finishing their courses or receiving their diplomas some students that were rather reluctant during their formal education days, later, particularly in their professional lives, took decisions and acted from feminist perspectives. These informal contacts made us very curious and inspired us to this study based on reviewing the gender perspective university courses for which we ${ }^{1}$ were responsible. The following is a critical reflection on how feminist perspectives, ${ }^{2}$ implemented as gender conscious pedagogy, can impact social justice in society by stimulating consciousness about equality, diversity, social rights and democracy, inside and outside the university.

In our opinion, knowledge of feminist theory and gender issues are related to knowledge-production as part of structural and relational aspects inside and outside universities today. According to Kathleen Weiler (1988), critical research framed by feminist theory shows how the concept of emancipation can be understood in the light of feminist epistemology. We connect this framework to our pedagogical project by integrating feminist epistemology using the concept "gender conscious pedagogy" which includes both teaching feminist theory and integrating feminist perspectives in both gender courses and courses in other disciplines in the higher education setting. Teaching gender perspectives aims at overcoming the "myth of objectivity", by questioning all mechanisms that create social injustices related to ideas of gender differences and "intersectionality" 3 . Integrating feminist perspectives in higher education includes putting gender matters on the agenda, promoting reflections about and analysis of societal problems, as well as discussing the meaning and limits of "normality".

The aim of this article is to take examples from a study and reflect on how teaching with gender perspectives (gender conscious pedagogy) in higher education courses can support students to be more confident about gender matters and, as a consequence,

\footnotetext{
${ }^{1}$ We, the authors of this article, have extensive experience teaching many gender courses at all academic levels, over a period of 20 years, at universities in and outside Sweden. This includes plain gender courses as well as courses on criminology, victimology, care science, entrepreneurship, working life, media and democracy with gender perspectives.

2 We the authors of this article stand for a feminist perspective against sexism, racism, homophobia and all forms of oppression.

${ }^{3}$ About an understanding of social complexity from a gender, sexuality, ethnicity, class, nationality, etc. point of view, and connecting it to reflections on power or power relations, (Crenshaw, 2006)
}

become gender actors outside the university in their personal and working lives.

Over the following pages we will describe how gender conscious pedagogy was implemented in the various courses we gave. We argue that, by using a gender conscious pedagogy, teachers can inspire students to make gender-reflections, generate greater equality in the classroom, and stimulate students to become gender-actors in society at large. This article is composed of the following parts: Theoretic standpoints, Collecting material on gender matters (method and material), Gender conscious pedagogy in practice (including analysis of material and discussions) and Conclusions. The questions to be examined are: How do we define gender-conscious pedagogy? What within the courses inspired the students to develop raised consciousness and self-criticism from feminist perspectives? How do students describe and reflect on their experiences in the gender courses? How do students exemplify their use of gender-knowledge outside the university?

\section{Theoretical Standpoints}

The approach used in this article is a norm-critical perspective on higher education (Lundberg \& Werner, 2012). Such a perspective entails criticism of traditional structures and discipline-cultures, which often obstruct, by dominance, real possibilities for consciousnessraising in education (MacKinnon, 1991; Weiler, 1988). Gender-structures are seldom questioned in traditional pedagogy and, at least in Sweden, are often invisible and absorbed without reflection by students whose lives have largely been shaped by social homogeneity norms.

In societies, inequalities can be identified in all social relationships as being temporary and fluctuating. Some inequalities last for a long time, over generations, and can be identified locally, nationally and globally. Long-lasting and systematic disparities, "durable inequalities", influence human beings' opportunities in life (Tilly, 2000). Structural distinctions affect us all -in our choice of education and study-subjects- as well as the choices we make in working life. Charles Tilly attributes the problem of "durable inequality" to socialization occurring from institutionalisations of the woman/man categories. This is done both deliberately and instinctively by inclusion, exclusion, adaptation and social control. The man/woman categories are causally related to dominance or subordination, which involves large and important differences in benefits related to gender (Tilly, 2000, pp. 19-26). Significant for understanding of gender relations is how power interrelates by structures and become norms that develop in processes of delegations (Young, 2000). This implies that "power relations" include mechanisms that are intimately integrated in social life. People, therefore, need knowledge in order to resist injustices (independent of whether the injustices are related to gender, ethnicity, 
sexuality, visible or/and invisible disability, etc.). Injustice can be defined as an act that aims at preventing freedom. The prevention of freedom occurs in different ways, for example restricting the individuals' own development and experiences as citizens or limiting the individual's or group's opportunity to participate, deliberate, and make decisions related to social issues. Resisting injustice requires a deeper understanding of gender knowledge and the implementing of feminist perspectives in teaching.

\subsection{Gender Knowledge}

Gender studies is closely connected to feminism, antiracism and sexual orientation activism and has, in common with these initiatives, a critique of discriminating structures. This (gender studies) approach deals with interpretations of discourses and their significance for human relationships, by analysing the effect of power structures (Connell, 2002). We define gender as a "social construction", within cultural and historical contexts, that is related to the social roles individuals are given or forced into in society. The perspective we apply in this study is not concerned with identity and, thus, as Connell (2002) puts it, has more to do with representation. We state that gender research has a political dimension in that it is related to liberation theory, social justice and democracy because it challenges patriarchal hegemonies and inequalities in society. ${ }^{4}$ Such a perspective on knowledge is a form of "activism" in the sense that it confronts questions related to the foundations of teaching as well as which individuals or groups in education have interpretive precedence. This is the perspective on knowledge that we apply in this article.

Central for understanding this focus is bell hooks' work, Teaching to Transgress (1994). According to hooks "education has a potential to be a practice of freedom":

When education is the practice of freedom, students are not the only ones who are asked to share, to confess. Engaged pedagogy does not seek simply to empower students. Any classroom that employs a holistic model of learning will also be a place where teachers grow, and are empowered by the process. (hooks, 1994, p. 21)

Activist knowledge necessitates a feminist perspective and promotes critical reflections on power as a central point of view. Reflection can be applied in the many situations that individuals (in this article, students) have to reflect upon using the terms of resistance against domination. A work of importance for our the-

4 For reference see hooks (2000); Eduards (2004); Enns (2005). oretical perspective is Feminism without borders (Mohanty, 2003), in which the author critically reflects on the role of a feministic hegemony and proposes a "pedagogy of resistance":

Creating resistance-cultures is about viewing the academy as part of a larger socio-political arena where people from the third world are neutralised and dealt with in the name of liberal democracy. (Mohanty, 2003, p. 241).

When resistance-cultures are created they open up new possibilities and new social views that are of central importance in order to develop criticism against the forms of repression and abuse we see in abundance in society today. Mohanty (2003) states that questions of knowledge, power and experience must be raised and reflected on, as contributions for pedagogic improvements.

Teaching by implementing feminist perspectives in higher education, therefore, entails a vision aimed at integrating education as part of a knowledge project with focus on equality and democracy. The intention is not only to focus on the concept of gender in its cultural context, but also to strive to recognise gender's various integrated social practices in teaching situations and in working life ${ }^{5}$.

\subsection{Implementing Feminist Perspectives in Teaching}

Subjects such as Gender Studies and Feminist Theory influence teaching; the didactic as well as the content of the education from a consciousness-raising standpoint. It would be contradictory to talk about democracy and injustice and simultaneously maintain a traditional, hierarchical teacher/student relationship in the lecture room. Such an arrangement would be hypocritical and unconvincing.

In consciousness-raising pedagogical processes, narratives, autobiographical presentations and memoryworks must be analysed and reflected upon contextually. Such processes develop new experiences and create deeper awareness and understanding of the problems in question. From a feminist point of view there is always a direct connection between the structural context and people's actions. Teaching and implementing feminist perspective, by using gender conscious pedagogy, stimulates students to confront their acceptance of "false consciousness". This can be done by reflections on prejudgments, as well as, revaluate conceptions of each other.

\footnotetext{
5 Concerning teaching situations see Lundberg \& Werner (2012) Genusvetenskapens pedagogic och didaktik (Pedagogic and didactic in gender science); concerning gender in working-life se for example Gonäs, Lindgren and Bildt (2001) Könssegregering i arbetslivet (Gender segregation in Working-life).
} 
Teachers must not forget that the students they meet in the classroom are also citizens with experiences of life and civil rights. In the classic work Pedagogy of the oppressed Paulo Freire (1993) states that when teachers and students proceed from their own experiences in dialogues, they contribute to an increased understanding, not only through their relationship to one another, but also to society in general. In other words, contexts are very seldom simplified but often deeply analysed and problematized.

The important thing, from the point of view of libertarian education, is for the people to come to feel like masters of their thinking by discussing the thinking and views of the world explicitly or implicitly manifest in their own suggestions and those of their comrades. Because this view of education starts with the conviction that it cannot present its own program, but must search for this program dialogically with the people, it serves to introduce the pedagogy of the oppressed, in elaborating what the oppressed must participate in (Freire, 1993, p. 105).

Generally, teaching in higher education (particularly in social sciences) has a critical reflective educational perspective. Therefore, it is an everyday challenge for teachers to develop pedagogic methods that interrelate "experiences" and "knowledge-seeking", that are not predetermined, states Sandra Harding (1991, p. 271). In relation to this idea, we argue that knowledge production involves various and different dimensions for many teachers. Essential to critical reflection is an epistemological perspective coupled with political awareness and knowledge of current praxis. These dimensions are closely related to "objective" ontological classifications such as structural oppression, discrimination, etc. But there is also a personal, more subjective, dimension required of one who makes choices of how to teach (for example, the feminist perspective). In other words, gender conscious pedagogy requires effort in order to inspire critical thinking and it entails a contribution to social justice, equality and democracy.

Our experience is that not all (students) are familiar with equality rights, conditions, and their implications and how this understanding relates to social distinctions. The concept gender conscious pedagogy involves, therefore, what we can call a "solidarity act", for example, helping students from minority groups to understand unjust situations in which they might be involved. By inspiring these students to explore and build understanding of their own situation and to analyse situations in terms of equal rights independent of social background, consciousness raising develops. Concretely, such experiences can be interpreted as "respectability" (Skeggs, 1999), but it often expands to a more open gender awareness. Feminist perspective implemented as gender conscious pedagogy in practice means acting and reflecting on breakthroughs, such as an understanding of how gender codes influence knowledge and education in general (not only humanities and social studies but also technology, entrepreneurship and care science, etc.) in everyday and working life.

\subsection{Gender Conscious Pedagogy}

What happens in a teaching situation is always unique because it is dependent on the communication between teacher and students. The situation specifically includes time/space situations. The purpose of using gender conscious pedagogy in the classroom is to inspire democratic dialogues and empower the students through this process. In general, classroom dialogues are based on the authoritarian role the teachers represent, but active gender pedagogy helps to break the silence in the lecture room and counteract the tradition of listening only to authorities. Thus, knowledge is created in the classroom by a two-way communication between teachers and students - the pedagogic tool is based upon the teaching and learning situation. Conversing through "emancipatory dialogues" aims at fulfilling, scientifically, deeper meanings of individual experiences as well as increased understanding of mutual experiences that develop in the teaching context. These are important elements for critically understanding what knowledge creation involves -at least in social science-in the sense that knowledge is intimately related to the experienced reality.

Implementing gender conscious pedagogy in the classroom can be described as a process related to socio-cultural-emotional context and, in practice, related to personal/relational contact. We cannot ignore the fact that what teachers communicate (at least within areas of social science) does affect the students as human beings. Critical dialogue involves difficult reflections in general because the interlocutors are students from different social classes, ethnicities, genders, sexual orientations, etc. Teaching embodies sensitive dimensions depending on how the subject matter is presented, especially when certain problem-formulations such as sexism and/or racism are treated. Some authors have concluded that, teaching based on a vision of consciousness-raising, (Cuesta, 2010) transforms "the classroom as democratic setting where everyone feels a responsibility to contribute is a central goal of transformative pedagogy" (hooks, 1994, p. 39).

\section{Collecting Material on Gender Matters}

This study includes a conceptualization of inequality regimes, connected to the production of gender knowledge. The starting point is a norm-critic perspective with reflections about the effects of implementing feminist perspectives in teaching which attempts a combination of theory and praxis. We highlight the im- 
portance of matters about gender awareness and gender conscious acting intended to benefit societies in terms of social justice, ${ }^{6}$ by situating people's experience and extending it to relational intersections. ${ }^{7}$

We have used a "critical hermeneutic" method in the sense that empirical material is mirrored and interpreted in light of the context in which the material is selected. "Hermeneutics is an approach to the analysis of texts that stresses how prior understandings and prejudices shape the interpretive process" (Denzin \& Lincoln, 2005, p. 27). Kincheloe and McLaren (in Denzin \& Lincoln, 2005) recommend the use of critical hermeneutics as a method that combines a critical view and a pragmatic approach to texts and their connections to the informants lived experiences. Hence, according to criticism, the contemporary societies (such as the Swedish) would not be understood as static and democratically unproblematic, but places where gender, class, ethnicity, sexuality and disability play an important role and influence the individuals' situation in terms of power relations.

When we interpret the students' answers and narratives about how they use knowledge from their education in their private and professional lives we have professional knowledge of education, society (as we are sociologists) and, in some cases, we have been able to follow some of the students and their professional careers (e.g. politics) using social media. We have also been able to follow a process of consciousness-raising with some of the participants.

The context in a classroom, using gender conscious pedagogy, includes a method for consciousness-raising aimed at making the classroom a democratic forum where responsibility, contribution to knowledgedevelopment and transformations in society become possible. ${ }^{8}$ We stimulated the students in our classrooms to reflections and discussions regarding ways in which power internalisation can be critically analysed; how emancipation can be achieved; and how individuals in society perform gender consciousness at large or by students in the classroom. Therefore, we define ourselves as a part of the study group in the classroom because, on one hand we represent a pedagogical view, while, on the other hand, we are open to be influenced by students. This influence may come from student statements that are particularly well focused, or, perhaps, situations related to equality and the experiences that students share. This method can be understood as a type of "knowledge- implied research" discovering, in particular, "the social as it extends be-

\footnotetext{
${ }^{6}$ See also Bartky (1990) and Acker (2006).

7 See also Smith (2005).

8 See hooks (1994) and Mohanty (2003), for further reflections connected to teaching in contexts of "colonisation/decolonisation".
}

yond experience", and implementing various techniques of data collection.

The material in focus in our study is based on both formal and informal communications. We gathered and analysed course evaluations, teachers' diaries with day to day notes and reflections, questionnaires to alumni students, face to face dialogues with students, parts of blogs and articles by some former students and articles about them and their work for gender equality in the media. Particularly useful to the study were the data from questionnaires collected from alumni students who were asked to remember and reflect upon their gender studies and about how useful the knowledge was/is in connection to their everyday and working lives. Our own voices, roles and work as teachers in these courses are also part of this study.

We had access to all the names of our former students but, unfortunately, in many cases their student email addresses were out of date so we had difficulty reaching all. Eventually, after searching for about 200 former students, we came in contact with 45 and received answers from 30 . The majority of the students who responded were female. ${ }^{9}$ Only three male students answered our questionnaire and contributed to the most significant part of the data. The collected material will not be treated as statistics but as short narratives (i.e. qualitative empirical data).

The teaching situations (usually lectures and seminars) evaluated were from Gender Studies and other courses with gender perspective such as entrepreneurship, care science, etc.) The content of the lectures ranged from classic and contemporary feminist theories and gender science to different topics and questions the students raised, often based on personal experiences and preferences. The seminars focused on discussions, interpretations and analysis. The lectures were based on theoretical viewpoints and concepts but also developed dialogues over theoretic references and the empirical cases. Two-way communication was an essential part of the knowledge development in the courses. In the next section, the students' voices and experiences with gender studies are presented.

\section{Gender Conscious Pedagogy in Praxis}

The common aim of the evaluated gender courses was knowledge development with regard to feminist theories related to gender consciousness (which in many sit-

\footnotetext{
${ }^{9}$ In Sweden 60,000 students gained $180 \mathrm{HE}$ credits, 65\% female and $35 \%$ male, in the academic year of 2010/2011. About $20 \%$ students had other background of origin than Swedish, the same amount as in the entire population (SCB, 2012; HSV, Report 2008:20R). Despite this, several fields and programs are heavily gender-dominated for example Technology ( $65 \%$ men), Care Science ( $82 \%$ women) and Teaching (78\% women). There are no official figures for Gender Studies but we have experienced that about $90 \%$ of the students in GS are female.
} 
uations lead to reflections about power structures and resistance against dominance). Below we present how former students remember, talk about, and act according to gender consciousness in their private and working lives.

The lecturers worked hard to involve students in settings designed for analysing their stories and narratives of real situations and life experiences related to the courses specific subjects. Text and film analysis, media analysis and topics such as equality, care science, and women's entrepreneurship were connected to the courses' focus on gender equality, human rights and democracy. We worked consciously to avoid simplifying problems of homogenous distinctions by talking about diversity and intersectionality including such issues as social class, immigration and sexuality. ${ }^{10}$

\subsection{Implementing Gender Conscious Pedagogy from Teachers' Notes}

Below we present a lecture series concerning conscious-raising:

The lecture series described below was included as one part of a gender-course at the first level. A majority of the student group did not have much knowledge about gender issues in advance. They choose Gender Studies, in general, out of personal interests but also because gender knowledge is a good qualification for working life in Sweden as complementary to other subjects. The lecture series was based on the book Feminism an Introduction by Jane Freedman (2003). Teaching in the course was based on diving into the field by implementing feminist theory to help define and understand gender issues and emerging problems related to power, domination and resistance. This is one dimension of using gender conscious pedagogy in the classroom. Another aspect of the course involved establishing conversations about common situations connected to daily life and to support critical reflections on them based upon theories drawn from Freedman's book. We tried to support the students' consciousness development by encouraging them to move from subjective feelings to more objective and intellectual understandings. The lecture series integrated three parts and was a developing process during the ten year period that we gave the plain gender courses. The following schedule shows a form of allembracing structure. This comprehensive model was then tailor-made and supplemented for the more specific courses such as entrepreneurship, care science, criminology and other subjects into which gender perspectives were integrated.

${ }^{10}$ An important detail to highlight is that one of us the teacher as a not Swedish origin.
"Feminism I", from empiric to theory: a) Students and teacher discuss some common situations in which gender structures can be identified. b) The teacher helps to relate emerging questions and themes to central concepts in the literature, aiming to help the students to be more open-minded and confident about the impact of gender and how it influences daily life. The discussions often started by the students sharing personal experiences and their common-sense understanding the teachers coached the students and inspired them to go deeper, to theorize and enter the gender theoretical field. The teachers' role was to be a coach and to be open-minded and support flexible interpretations when it came to analysis of common situations well known to the students. In this way, the first step was taken to develop critical reflections about gender and power relationships based on feminist theories. The next step was to generalize about problems and use consciousness as a tool to stimulate students to reflect on good or bad societal changes. For such development to occur, a deeper knowledge of the history of the field of feminism is necessary as well as knowledge about convictions, gender structures and empowerment. c) The teacher can, for example, create a map on a white board to display central concepts and their relations to central theories. The map becomes a starting point for papers (empirical to theoretical) that students present later, and discuss in a seminar.

"Feminism II", deepening in theory: a) The teacher returns to the concept map from earlier lectures and reinforces the impact of central gender theories and concepts connected to the literature. The students are encouraged to be actors and to help develop the map and raise questions at any time. b) The object of this process is active student participation in order to develop a deeper understanding of the contributions of gender studies and social changes. It is intended that the students become conscious of societal influences on individuals. c) The work in seminars becomes the basis for more extensive theoretical papers, which are presented and discussed later, in another seminar.

"Feminism III", individual deepening: a) The teacher shows illustrations of different issues and matters from media, (daily newspapers, magazines, Internet, social media etc.) in order to visualise the impact of gender as a norm to be conscious of and critical about. b) The students reflect on and discuss the given examples and suggest theoretical angles to analyse them in small groups (for example about masculinity). c) A list of topics is created in order to help in the examination connected to this part of the course with focus on "from empirical to theoretical". 


\subsection{Remembering Classroom Situations...from Students' Narratives}

Below, some students describe different experiences concerning consciousness-raising in the classroom:

- The studies of hegemonic masculinity were very interesting and gave me many insights. It gave me an aha-reaction on how complicated the gendersystem is and further problems. We had good discussions and analysis together with the teachers and the whole course equipped me with good basic knowledge on gender and with tools for my work as a professional politician (Ingrid, political science, politician in local government)

- Reading the book "Forbidden action" and taking part in the seminar gave a specific understanding of how provoking it obviously can be for some people that women (individually or as a collective) can manage on their own, without men. It was surprising, not necessarily because I did not know it before, but it was suddenly so clear to me after this item. (Martin doctoral student in Education)

- I remember when we analysed a television drama series and received some questions about colonization. One question was about status and power. I think about that now and then-how we value an immigrant differently based on which country he or she comes from. (Erica, master in Ethnology, research secretary)

- The discussions we had in class and in minor groups opened many doors to new ways of looking at gender equality, on the shape of the society and on how we can change it for the best. (Anna, student in social psychology and handcrafter)

- The studies gave me a wider understanding of the relation between the individual and the society and groups that are defined as outsiders in the normsociety (Carina, BA sociology, probation officer)

- Multi-culture was an important part of the course. (Fanny BA sociology, youth pedagogue)

- I started with an open mind and my eyes opened up, I learned new things all the time and came to look upon my environment with a new perspective. (Daniela student and local politician)

\subsection{Interpreting Gender Conscious Pedagogy in Classrooms}

Gender conscious pedagogy often results in eyeopening moments as we see in the above quoted, notes and narratives. Gender consciousness also stimulates emancipation and self-criticism, which, in the courses in focus, necessitated that we as teachers consciously acted to involve the more silent, sceptic or unsure students to take up a standpoint and dare to raise their voices. The purpose for stimulating and encouraging the quiet students to do this was to make sure that their understanding of theories and concepts like power-techniques, norms, roles, discrimination, injustice and democracy did not stay at an academic level but could be illustrated with and related to the students' personal experiences on descriptive as well as analytic levels. At the lectures, we, as teachers, often worked deductively because of the "atmosphere" in the classroom. In seminars we worked inductively because of the many experiences the students wanted to relate and try to understand. As most teachers are aware, students raise their voices in small groups better than in front of the whole class. The seminar leaders consciously enabled students to actively participate and tried to lead the discussions away from the mere relating of individual examples/problems toward expressions of deeper intellectual and theoretical understanding.

The students' narratives regarding courses they had taken 3-7 years ago reinforce the starting point of the pedagogy in focus. We are also encouraged that the students questioned tell us that they internalized and used the gender knowledge from the course in their everyday lives and working lives. We were pleased to see that many of these students, even if they could not point out a specific moment, wrote that the entire course gave them a deeper understanding of the mechanisms of gender structures and power strategies. We are aware that students with negative experiences in the courses might not have bothered to answer our questionnaire. ${ }^{11}$ Some students pointed out that the discussions in seminar groups had been particularly valuable to them because they could go deeper and analyse what we call "false consciousness" about gender roles in society.

The narratives we gathered show that the respondents' experiences of raised consciousness, enabled them to use various gender-related concepts and norm-critical perspectives to interpret their social environment. One respondent, Ingrid, uses a lot of concepts related to gender theory from the lectures and also refers to theories like gender-system and hegemonic masculinity when she refers to discussions in and analyses of the course she took. Furthermore, she describes an aha-reaction to the gender-complexity of problems. Another respondent, Martin, also refers to a specific moment he had while reading literature that can be described as "consciousness raising", one of the aims of the course. Erica's reflections on how ethnicity

11 In general terms we received very positive answers from the respondents, but what kind of information we missed from the ones that did not respond, is impossible to know. Nevertheless we find that the collected material is significant for our purpose-even a small sample can be rich in information-because it is representative in order to "raise their voices". 
can play a role in everyday life while "valuing" people, started with an analysis of a television drama that was analysed as part of a seminar.

In general, the narratives express how a consciousness-raising process influenced the students' awareness of key perspectives of gender equality as well as how such awareness can help understanding and, possibility, change society. Fanny describes her experience as creating a wider understanding of alienating structures and norms in society. Other side the concept of multi-culture was interpreted and connected in a Swedish context. This is an example of how the gender conscious pedagogy can be related to a norm critic view on society.

\subsection{Being Gender-Actors in Working Life...from the Students' Narratives}

Below, some students describe their personal development and awareness concerning gender and equal rights as well as diversity and democracy issues:

- My self-confidence is much better since taking the course Women's entrepreneurship. Now I dare to say no to things I do not want to do and I have the courage to raise demands, for example, when talking to the bank. (Karin, small business manager, horse breeding)

- I am not "the nice little girl" anymore-I now know that it's much better to make my voice heard. People actually listen to me now. (Lisa, small business in health care)

- I work at a University where topics of gender, diversity and democracy are constantly on the agenda although I do not work with them explicitly. I developed a more analytical way of looking at things and have been able to decode certain behaviours at work, for example, when someone uses power techniques against me or someone else. (Erica, research secretary)

- I have developed knowledge and gender awareness that I try to use when interacting with children and, not least, with their parents in the gymnastic group I lead. (Anna, student in social psychology and handcrafter)

- I wish for and seek another perspective on social work in which I can use my knowledge from my education. Today, I appreciate the knowledge about power relationships, gender equality, etc. in my work with people and in relationships with my colleges. (Carina, BA sociology, probation officer)

\subsection{Being Gender-Actors outside the University...from Students' Narratives}

Below some students describe their experiences concerning gender acting.
- I use a lot of the knowledge in my life. For example, I have demanded that the Political Region uses gender-divided statistics to make the health and medical services more equal. I have also highlighted the question of violence in intimate relationships on the agenda. (Daniela, MA student and local politician)

- I am sure it (the course) has influenced how I look at my social environment. One example of when I use my gender knowledge is at salary negotiations, when it comes to my own salary as well as when it comes to me negotiating with my colleagues about their salary. (Greta, MA IT management, IT consultant)

- I have had a lot of use of my studies. As one of the leaders of the City Council I have a lot of power and meet power structures every day. I have been very much helped by understanding and knowing about power techniques, power structures and gender systems strata and its manifestations. Equality, democracy and diversity are often problematized and it is good to have theories to lean on, not only personal experiences. (Ingrid, politician, local government)

- I definitely received knowledge about gender, ethnicity and equality that set the tone for my dissertation and the topics that I teach today. I also have great use for the knowledge in private as well as in working life in order to discover, understand and tackle power structures of different kinds. (Berit, PhD, sociology)

- The course stimulated a "critical gaze" that has an essential importance for my picture of the world and perspective on society, groups and social relationships. Gender-consciousness is a natural part of my doctoral studies. As a dramatist within amateurtheatre I try to make "gender experiments" dealing with the fact that most of the members are female but most of the existing plays are dominated by male roles. You could continue to let girls play girls but let the female characters fill functions in the plot that are usually ascribed to male characters. Another way of dealing with this paradox is to make some of the characters more androgynous. (Martin, doctoral student)

\subsection{Interpreting Gender-Actors in Society}

To understand norms and power and their implications in terms of equality, justice and democracy is the aim of gender conscious pedagogy. The consciousnessraising process entails responsibility for both the teachers and the students interacting in classrooms. The classrooms can also be understood as working places and, relationally, as small societies. Classrooms present obvious opportunities, according to Freire (1993), hooks (1994) and Mohanty (2003) to reflect 
about the meanings of power and situations when breaking norms contributes to more equality, justice and democracy.

The narratives from the students express that gender consciousness not only influences their private lives but also their professional lives. Karin and Lisa (both from a course on gender and entrepreneurship) talk about better self-confidence and daring to raise their voices now. They feel that they are actually listened to now. They show that they have gained respectability as women and entrepreneurs -a product of awareness and emancipation, we believe-. Erica (from an ordinary gender course) uses her knowledge of power techniques in her working life as a research secretary in a big city medical institution. Anna (from an ordinary gender course) shows that she can use gender knowledge when interacting with children and their parents as leader of a gymnastic group in a small village -questions of awareness and implementation of rights and equality-, we believe. Carina (from an ordinary gender course) has used gender knowledge when interacting with colleagues and former inmates at a probation office. Her job deals with power relations and equality and she hopes for "another" perspective on social work -acquiring a gender perspective-, we believe. Daniela, (a politician today) was a skeptical student from the beginning. Therefore, it is particularly interesting to see that she is such an engage person when it comes to her political actions. The example she illuminates (gender divided statistics) relates to a seminar connected to an ordinary gender course. Gender knowledge enabled her, to reach a power position in society -a question of breaking norms and moving up in power situations-, we believe. Greta exemplifies how gender knowledge can be used at salary negotiations in a rather early part of working life in the IT sector. She is aware of income differences between male and female professionals but she neglects to let that decide how she acts in such situations -a question of justice and equality-, we believe. Ingrid (politician) says that she meets power strategies every day and is aware that these strategies influences her even though she has a lot of power herself -a question of emancipation connected to democracy-, we believe. When major questions of equality and democracy are on the agenda it feels good to be able to use the theories from her education, she says. Berit took gender studies to a higher academic level as an integral part of her dissertation. She also uses gender knowledge in her own teaching at the university-acquiring a gender perspective-, we believe. Martin (doctoral student and dramatist) has developed a critical gaze, particular in his analysis of the world. He expresses that sometimes when he experiments with the actors' gender roles on stage where most of the actors of the group are female and most of the written roles are for males. He addresses this problem and sometimes makes the roles more androgynous
- a question of breaking norms and equality-, we believe. When he does this, he plays with or extends the traditional limited gender roles that were problematized during the course he took.

\subsection{Discussion}

Reflecting on democracy and power issues and inspiring students to critical thinking demand pedagogical tasks involving the impact of gender knowledge on students' roles as actors in relation to structure, particularly in connection to working life. Being a gender conscious actor should not be understood as a consequence of a process but, rather, as a developing process in itself that includes teaching and learning, critical viewpoints, case methodology, self-reflection, raising one's voice and conscious action, particularly in connection to situations involving dominance and subordination. This implies that teachers and students integrate critical viewpoints into every social situation including personal development. In other words, the social construction of a given (gender) role often entails a positioning in terms of "changing values," and a contrast to existing norms. ${ }^{12}$ Gender conscious teaching entails a social responsibility in terms, which highlight gender equality in practice. It is our interpretation that gender conscious pedagogy can stimulate students to a deeper understanding of the imperatives they have as citizens in a democratic society. Specifically, when lectures focus on gender issues, they undoubtedly open up opportunities for everybody involved to be more self-confident in their gender roles in society.

We believe that the pedagogical tools used in the courses that were the focus of this study stimulated the students to self-reflections and social interactions in line with the aims of critical gender studies. Gender conscious pedagogical perspectives, as well as pedagogical practices were tools used to help the students to reflect about their lives: a) with critical reflections on power relations-structural perspective; b) on how emancipation can be constructed-process perspective; c) on how gender is performed by individuals/students in society/classrooms-individual perspective. We believe that the possibility of becoming a gender-conscious actor must include awareness of all three perspectives and how they are interrelated, i.e. the context/the tools/the individual (Cuesta, 2010).

We also want to highlight the fact that the pedagogical tool we used in the courses is based on a twoway communication between teachers and students and that teaching in both large and small groups help students to be self-confident. The content and the teaching methods utilized opened up opportunities and allowed students to reflect on and comprehend the different social contexts from which they came and

12 See also Scott (1999). 
how social boundaries impact everyone. The inclusionary perspective (i.e. interacting and exchanging experiences) is based on included agreements as well as confrontations, in the sense that communication between students and between students and teachers can sometimes be defined as critical experiences when the communication concerns, for example, sexism or racism. One important point to highlight here is that meetings between students and teachers for exchanging experiences and knowledge become part of everyday life; hence the theoretical is implemented in daily life. In these meetings, strong feelings and emotions are involved and, in the long run, as we see in the quotes from the students, new experiences inspired them to gender conscious actions even outside the university. Both female and male students were supported when reflecting on their roles as parts of structural oppression, not only as part of a subordinated or a superior category, but also as passive or/and active participants. This is an important issue because not everyone was aware of gender issues when they started the courses. Sometimes students, as people, accept their given role based on gender, ethnicity, sexuality, disability, etc. in a fundamental way as a result of difficulties in adopting other roles. Such realizations are of central importance in the pedagogical process where the teacher must become an involved actor in discussions. In such cases, the students are often keen to discuss topics and personal examples resulting in more indepth communication and increased understanding.

\section{Conclusion}

The pedagogy we focus on in this article, was inspired by emancipatory statements connected to knowledge production, according to Freire (1993), hooks (1994) and Mohanty (2003). This pedagogy requires an understanding of power relations in complex situations where gender, sexuality, ethnicity, class, nationality, etc. interact in terms of a politic of identity. The students in the study were all Swedish students but some were connected to other countries of origin, which influenced discussions in class and individual consciousness about citizens' rights in the complexity of a democratic society.

The courses evaluated and analysed were based on gender lectures and seminars in which issues of gender and equality as well as social justice and democracy were in focus. Content spread from central theories to examples from everyday life that integrate personal experiences and preferences. Lectures were based on theoretical standpoints and concepts but also developed dialogues about theoretic references and empirical cases. Seminars attended to more specific empirical cases. Gender conscious pedagogy, according to the conceptual framework of this study, deals with a consciousness-raising process by breaking traditional "gender knowledge", by inspiring new "gender strategies" and by questioning the acceptance of hegemonic values. ${ }^{13}$ Using "gender conscious pedagogy" in everyday teaching situations results in varying interactions and actions in which both teachers and students exchange shared experiences. Opening classrooms, on one hand, to processes dealing with democracy and social justice and, on the other hand, implementing gender consciousness by social interactions.

We want to emphasize that we cannot fully know to what extent we have influenced the students to become what we call gender actors. Our conclusions are inferences based on their narratives, their blogs and articles, and our own experiences as teachers. Students, like other categories of humans, are not a homogeneous group and we are quite aware that, when they come to a course, they are at different states of gender consciousness. The narratives we analyzed strongly suggested to us that the courses in question had stimulated influenced and involved various students in gender issues to one degree or another.

Finally, the focus of this article has been to illuminate that teaching from a feminist perspective opens up opportunities for all citizen-students, especially those from repressed groups, to be aware of and to be able to act against injustices in working life as well as in personal life. This kind of knowledge should not be understood as or limited to criticism about sexism and racism. It is a question of democracy.

\section{Conflict of Interests}

The authors declare no conflict of interests.

\section{References}

Acker, J. (2006). Class questions: feminist answers. Lanham, MD: Rowman \& Littlefield.

Bartky, S. L. (1990). Femininity and domination: Studies in the phenomenology of oppression. New York: Routledge.

Connell, R.W. (2002). Om genus [On gender]. Göteborg: Daidalos.

Crenshaw, K. W. (2006). Mapping the margins: Intersectionality, identity politicss and violence against women of color. Kvinder, køn og forskning, 15(2-3), 3-20.

Cuesta, M. (2010). (Själv)biografisk subversion. In Tidskrift för Genusvetenskap, Tema: Självbiografi. Nr. 4 (pp. 72-75). Linköping: Linköpings universitet.

Denzin, N. K., \& Lincoln, Y. S. (2005). Qualitative Research, 3rd. ed. London: Sage Publications.

Eduards, M. (2002). Förbjuden handling [Forbidden action]. Stockholm: Liber.

Enns, C. Z., \& Forrest, L. M. (2005). Teaching and social

${ }^{13}$ See also Mohanty (2003). 
justice: integrating multicultural and feminist theories in the classroom. Washington, DC: American Psychological Association.

Freedman, J. (2003). Feminismer [Feminisms]. An introduction. Malmö: Liber AB.

Freire, P. (1993). Pedagogy of the oppressed. London: Penguin Books.

Gonäs, L., Lindgren, G., \& Bildt, C. (2001). Gender Segregation in Working-Life. Stockholm: National Institute of Working-Life.

Harding, S. (1991). Whose science? Whose knowledge? Thinking from women's lives. Ithaca: Cornell University Press.

hooks, b. (1994). Teaching to transgress: Education as the practice of freedom. London: Routledge.

HSV. (2008). Högskoleverket, Rapport 2008:20R. Kvinnor och män $i$ högskolan [Women and men in higher education].

hooks, b. (2000). Feminism is for EVERYBODY. London: Pluto Press.

Lundberg, A., \& Werner A. (2012). Pedagogy and Didactic in Gender-Science. Gothenburg: National Council of Gender-Science.
MacKinnon, C. (1991). Towards a Feminist Theory of the State. Cambridge: Harvard University Press.

Mohanty, C. T. (2003). Feminism without borders. Decolonized theory, practiced solidarity. Stockholm: Tankekraft förlag.

SCB. (2012). På tal om kvinnor och män, Lathund om jämställdheten. [Talking about women and men. Quick reference on equality].

Scott, J. W. (1999). Gender and the politics of history. New York: Columbia University Press.

Skeggs, B. (1999). Respektabilitet. [Respectability]. Uddevalla: Daidalos.

Smith, D. (2005). Institutional ethnography: A sociology for people. Walnut Creek, CA: AltaMira Press.

Tilly, C. (2000). Beständig ojämlikhet [Durable inequality]. Lund: Arkiv.

Weiler, K. (1988). Women Teaching for Change: Gender, class and Power. South Hadley, MA: Bergin \& Garvey.

Young, M. I. (2000). Inclusion and democracy. Oxford: Oxford University Press.

About the Authors

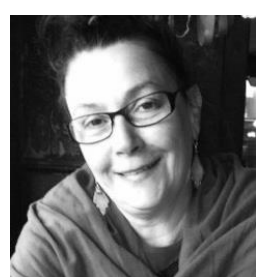

Dr. Marta Cuesta

Marta Cuesta is associate professor in sociology at the Department of Health and Society at the University of Halmstad, Sweden. Marta is coordinator of an International educational exchange, funded by the Linnaeus Palme. Her research interests include critical sociology, educational sociology, and postcolonial feminism. Marta is member of the head panel at a Research Center of Social Analysis, Cesam, also member of the International Sociology Association, ISA: Sociology of Education.

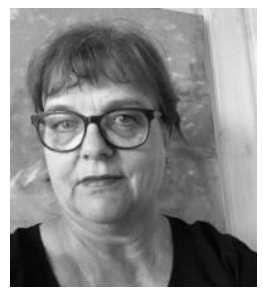

Dr. Ann-Katrin Witt

Ann-Katrin Witt is PhD in and lecturer of Sociology, equal opportunities and gender relations at the Department of Health and Society, University of Halmstad, Sweden. Her research interests focuses on gender, work and welfare and extended areas such as equal opportunities, craftsmanship; gender and higher education; gender in criminology and victimology. She is member of the research group Public Health and Sustainable Development at UH, and International Sociology Association, ISA: Sociology of Education. 


\section{Appendix}

Questions via e-mail to alumni students about their experiences of courses at Halmstad University that were based on gender and diversity-perspective.

Write your answers under the questions.

1. What course did you study?

2. What is your highest degree?

3. Describe your profession, your tasks, any political or non-profit assignments or anything else that you think may be of relevance for this study:

4. The courses included studies on gender, diversity, equality and democracy. Did you develop knowledge about this that you can use today in our professional life? Do you have any examples of this that you can describe shortly?

5. Do you remember any specific occasion or moment during your studies on the above-mentioned course that has been of a specific importance to you concerning your perspective on people and equality among people everywhere?

6. Would you like to tell us anything else that you think might be useful for our study?

Thank you for taking part in this study! 